\title{
Biodegradation of Aflatoxins by Bacteria
}

\author{
Seham Abdel-Shafi(1)\#, Sabry Shehata ${ }^{(2)}$, Ahmed Shindia ${ }^{(1)}$, Khaled El-Meligy ${ }^{(3)}$ \\ and Asmaa Khidr(1) \\ (1)Botany and Microbiology Department, Faculty of Science, Zagazig University, \\ Zagazig, Egypt; (2) Animal Production Department, Faculty of Agricultutre, Zagazig \\ University, Zagazig, Egypt; (3)Regional Center for Food and Feed, Agricultural \\ Research Center (ARC), Giza, Cairo, Egypt.
}

\begin{abstract}
FLATOXINS (AFs) have great side effects on human, animals and crops. It causes severe illness to both human and animals and play a major role in economic loss. Biological decontamination seems to be attractive. The present investigation aimed to found new and safe microorganisms able to degrade AFs and inhibit its producing fungi. Forty three bacterial isolates were isolated from different cultivated soils and animal feces. All isolates were screened for their ability to degrade AFs using thin layer chromatography (TLC). Nine bacterial isolates were able to degrade AFs using TLC and HPLC. HPLC results showed that AFs degradation ratio higher than $90 \%$ occurred by 3 bacterial cultures. The identification of the highly degrading isolate CaG6 (with $98.1 \%$ degradation ratio) was established by using 16S rRNA gene sequencing as Bacillus cereus. Then sequence was acquiesced to GenBank in accession number MG 751322 with $99 \%$ similarity to Bacillus cereus. Bacterial isolates CaG7 and IsW1 (with 94.6, 90.7\% degradation ratio, respectively) has been identified by MALDITOF MS using the VITEK MS system (bioMérieux) as Brevibacillus $\mathrm{sp} 1$ and Brevibacillus sp2. Results showed that cell cultures (viable cells) were more effective in the degradation of AFs than cell free supernatant (CFS), while ppt exhibited no degradation. The three bacteria not only reduced AFs but it could also inhibit Aspergillus flavus NRRL 3145 with inhibition zone $\geq 20 \mathrm{~mm}$ after incubation for $96 \mathrm{~h}$ at $28^{\circ} \mathrm{C}$. The AFs degradation by B. cereus, Brevibacillus sp 1 and Brevibacillus sp2 enhanced by addition $\mathrm{Mn}^{+2}$ ions to the liquid media.
\end{abstract}

Keywords: Aflatoxins (AFs), Bacillus cereus, Aspergillus flavus, TLC and HPLC.

\section{Introduction}

Outside of 400 kinds of mycotoxins have been recognized, only about $10-15$ have a public health interest (Turner et al., 2015). Aflatoxins (AFs) are toxic secondary metabolites of Aspergillus flavus, Aspergillus parasiticus and Aspergillus nomius (Zhu et al., 2016). From 18 different types of aflatoxins, as $B_{1}, B_{2}, G_{1}, G_{2}, P, Q, M_{1}, M_{2}, B_{2}$ a, etc., were recognized, the most distributing ones in fungal cultures are aflatoxins $\mathrm{B}_{1}, \mathrm{~B}_{2}, \mathrm{G}_{1}$ and $G_{2}$, then aflatoxins $M_{1}$ and $M_{2}$ in milk (Wu et al., 2009). B- and G-type AFs has been classified by The International Agency for Research on Cancer

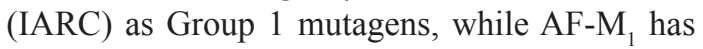
been classified in Group 2B (IARC, 2015).

Corn, peanuts and cotton seed are the most affected crops in addition to rice, soybean and pistachio that can be extremely contaminated (Oplatowska-Stachowiak et al., 2016). It is expected to cause more than $28 \%$ of the total global cases of hepatocellular carcinoma (HCC) (Wu, 2014). AFs affect a wide diversity of animals comprising poultry, turkey, fish, rodents, swine, cattle and humans (Afsah-Hejri et al., 2013). Strong exposure to AFs causes growth delay in young children (Lombard, 2014). Recent studies carried out on the mice showed that the early exposure to the $\mathrm{AFB}_{1}$ in particular at the embryonic period is amutagen (Chawanthayatham et al., 2015).

Harmful effects caused by this dangerous toxin have directed researchers towards finding new strategies for prevention and detoxification in order to preserve the safety of products intended for human consumption (Ben Salah-Abbes et al.,

\#Corresponding author email: hegazyseham@yahoo.com

$\mathrm{T}:+201289600036$ 
2015). The efficiency of aflatoxin detoxification relys on different factors, including food conditions (food constituents, moisture content and $\mathrm{pH}$ conditions), detoxification technologies and conditions (Pankaja et al., 2018).

Therefore, several approaches have been applied to detoxify AFs in crops and during postharvest (Spadaro \& Garibaldi, 2017), as physical, chemical and biological methods (Siciliano et al., 2016). The chief problems with chemical and physical methods are their restricted range of effect on different mycotoxins and some chemicals may lead to drop in animal health. Moreover, there is a common drawback of physical and chemical treatments, since they may also cause a significant decline in the quality of food products (Prettl et al., 2017).

Over the past decades, The use of selected microorganism to control mycotoxins toxification and postharvest disease has greatly increased, providing an attractive alternative tool for removing toxins and safeguarding the value of food and feed (Wambacq et al., 2016). Some strains of lactic acid bacteria, Aspergillus parasiticus, Trichoderma viride, Mucor ambiguus and other fungi were able to degrade $\mathrm{AFB}_{1}$ with different ranges (Cao et al., 2011). Terrestrial bacteria are a group of antagonistic microorganisms able to inhibit toxigenic fungus growth and AFs production (Siahmoshteh et al., 2016).

The aim of this study was to achieve biological degradation of aflatoxins by bacteria and fungi using the following approach: 1Isolation of bacterial isolates from cultivated soils and animal feces, 2- Purification of bacterial isolates and Screening the ability of its fractions (cell free supernatant, cell precipitate (ppt) and viable cells) on the degradation of aflatoxins, 3Identification of the most potent bacterial isolates in degradation of aflatoxins by TLC and HPLC and 4- Examine the factors affecting degradation of aflatoxins by the best fraction.

\section{Materials and Methods}

\section{Sample collection}

Bacterial species were isolated from soils and animal feces from different governorates in Egypt including Sharkia, Dakahlia, Cairo, Ismalia and Tanta. These soils were cultivated with wheat, trifolium, cabbage, garlic, onion and potato, respectively. Also samples from different animal feces including feces of horse, pigeon, sheep and buffalo were collected. Fourty-three bacterial isolates were screened for their ability to degrade aflatoxins.

\section{Culture media}

Coumarin nutrient agar medium (CMNAM) consisted of $5.0 \mathrm{~g}$ peptone, $2.0 \mathrm{~g}$ yeast extract, $1 \mathrm{~g}$ lab-lemco powder, $5.0 \mathrm{~g} \mathrm{NaCl}, 15.0 \mathrm{~g}$ agar and $2.5 \mathrm{~g}$ coumarin per liter $(\mathrm{pH}=7.0)$. Nutrient agar (NA) and nutrient broth (NB) were prepared according to Monica (1985) for bacterial colonies preservation. Czapek - Dox's agar medium (CD) which prepared according to Oxoid (1982) for preservation of AFs producing fungi.

\section{Isolation and purification of bacterial isolates}

Bacterial colonies isolated and counted using standard dilution plate procedure (El-Shirbiny, 1990). About 25g of each soil sample and animal feces were placed in $500 \mathrm{ml}$ Erlenmeyer flask. Sterile water was added to the soil and feces until the total volume of $250 \mathrm{ml}$ reached $10^{-1}$ soil dilution. This soil and feces dilution were stirred by stirrer until suspension obtained. The suspension was left to stand for sedimentation of soil and feces matter. The supernatant was serially diluted till reached $10^{-7}$. One $\mathrm{ml}$ aliquot of each dilution was transferred aseptically to petri dishes containing $15 \mathrm{ml}$ of CMNAM. Colonies that were able to grow on the medium were selected, purified and preserved as pure isolates on nutrient agar and tested for aflatoxins degradation.

Screening the ability of bacterial isolates on the degradation of aflatoxins $\left(B_{1}, B_{2}, G_{1}, G_{2}\right)$ by TLC analysis

The standard mixture of four types of aflatoxins (AFs) were kindly provided by Dr. Khaled El-Meligy from Regional Centre for Food and Feed, Ministry of Agriculture, Giza, Egypt. Bacterial isolates were cultured NB, $(\mathrm{pH} 7.0)$ at $37^{\circ} \mathrm{C}$ in shaker incubator for $48 \mathrm{~h}$, then $200 \mu \mathrm{l}$ of each bacterial culture was transferred to $5 \mathrm{ml} \mathrm{NB}$ medium. The medium inoculated with $100 \mu \mathrm{l}$ of AFs methanol stock solution from standard AFs $\left(500,150,500\right.$ and $150 \mathrm{ppb}$ of $\mathrm{AFB}_{1}, \mathrm{AFB}_{2}, \mathrm{AFG}_{1}$ and $\mathrm{AFG}_{2}$, respectively) (Shehata, 2002).

The detoxification tests were conducted in the dark at $37^{\circ} \mathrm{C}$ on a rotor shaker for $24 \mathrm{~h}$. The AFs was extracted from the cultures by 
adding $5 \mathrm{ml}$ chloroform, mixed well for $5 \mathrm{~min}$, transport to separatory funnel, left until stand, the bottom layer was drained in clean flask and the chloroform extracts were evaporated to dryness then AFs detected by TLC.

Screening the ability of bacterial cultures on the degradation of aflatoxins by HPLC

The residues of dried AFs extract were dissolved in $0.5 \mathrm{ml}$ of water:methanol:acetonitril (54:29:17, v/v/v) and analysis. The total AFs content was determined according to AOAC (2006) method using monoclonal antibody columns for total AFs (VICAM Science Technology, Watertown, MA, USA). Aflatoxin identification was performed by a modification of the HPLC-Afla test procedure Agillent 1200 Series USA. HPLC equipment with two pumps, column C18, Lichrospher 100 RP-18, $(5 \mu \mathrm{m}$ * $25 \mathrm{~cm}$ ) was used. The mobile phase consisted of water:methanol:acetonitrile $(54: 29: 17, \mathrm{v} / \mathrm{v} / \mathrm{v})$ at flow rate of $1 \mathrm{ml} / \mathrm{min}$. The excitation and emission wavelengths for all AFs were 362 and $460 \mathrm{~nm}$ (Flourcenses detector), respectively.

Degradation of AFs by bacterial cell free supernatant (CFS) and cell extract using TLC and HPLC analysis

Fresh NB was inoculated with $12 \mathrm{~h}$ pre-cultured bacterial isolates $(200 \mu \mathrm{l})$. Inoculated cultures were incubated at $37^{\circ} \mathrm{C}$ with agitation at $200 \mathrm{rpm}$ for $24 \mathrm{~h}$ in a shaker incubator. The preparation of supernatant was carried out following the method of Teniola et al. (2005) with slight modifications. After incubation, bacterial isolates were centrifuged with $4000 \mathrm{rpm}$ for $20 \mathrm{~min}$, The precipitate (ppt) was harvested and the resulting culture supernatant was filtered aseptically using sterile cellulose pyrogen free disposable filters of $0.2 \mu \mathrm{m}$ pore size. AFs methanol stock solution $(100 \mu \mathrm{l})$ was added to $2 \mathrm{ml}$ culture supernatant and ppt then the reaction mixtures were for $24 \mathrm{~h}$ in the dark with agitation at 200rpm in a shaker incubator. The AFs degradation tests were performed as described before.

Effect of the most potent bacterial isolates on antifungal activity by disc diffusion assays

Aspergillus flavus NRRL 3145 was kindly provided by Dr. Khaled ElMeligy, Regional Centre for Food and Feed, Ministry of Agriculture, Giza, Egypt. Sterilized discs of filter paper $(6 \mathrm{~mm}$ diameter) were soaked in $1 \mathrm{ml}$ of each isolated bacterial suspension, for $2 \mathrm{~min}$; they were then placed onto agar plates that were previously seeded by cell suspension of the indicator fungi used (A. flavus). After incubation for 4 days, diameter of inhibition zones $(\mathrm{mm})$ were measured after subtracting diameter of paper disc (Saeed \& Tariq, 2007).

\section{Characterization of B. cereus MG751322}

Determination of $16 S$ rRNA gene sequence

DNA extraction was done by using (QIAamp DNA Mini Kit Catalogue no.51304) according to the manufacturer's instructions. PCR- mediated amplification of the $16 \mathrm{~S}$ rDNA, purification and sequencing of the PCR products were done by QIAquick Gel Extraction Kit Protocol: Using QIA quick gel extraction kit. (Qiagen Inc. Valencia CA). The primers used for amplifying and sequencing were: $27 \mathrm{f}$ (5'AGAGTTTGATCMTGGCTCAG - 3') and 1492r (5'TACGGYTACCTTGTTACGACTT -3') (Source: Metabion, Germany).

\section{Phylogenetic analyses}

A comparative analysis of sequences was performed using the CLUSTAL W multiple sequence alignment program, version 1.83 of MegAlign module of Lasergene DNAStar software Pairwise, which was designed by Thompson et al. (1994) and Phylogenetic analyses were done using maximum likelihood, neighbour joining and maximum parsimony in MEGA6 (Tamura et al., 2013).

Effects of incubation period, temperature, $p H$, and metal ions on AFs degradation by B. cereus MG751322

Bacterial isolates cultivated in nutrient broth (NB) for 24h, after incubation, viable cells were tested for AFs degradation. AFs methanol stock solution $(100 \mu \mathrm{l})$ was added to $(200 \mu \mathrm{l})$ pre-culture bacterial isolates in a $5 \mathrm{ml} \mathrm{NB}$. The reaction mixtures were incubated in the dark at $37^{\circ} \mathrm{C}$ without shaking for $1,12,24,48,72$ and $90 \mathrm{~h}$, respectively. To determine the effect of temperature, the mixtures were incubated at 20 , 30 and $37^{\circ} \mathrm{C}$, respectively for $24 \mathrm{~h}$. Controls were set at this temperatures by using NB medium (according to Guan et al., 2008 with modification).

In the $\mathrm{pH}$ tests, initial $\mathrm{pH}$ value was obtained by adjusting $\mathrm{pH}$ to $4.0,5.0$ and 6.0 with $1.0 \mathrm{~N}$ $\mathrm{HCl}$ buffer, and to $7.0,8.0$ and 9.0 by $1.0 \mathrm{~N}$ $\mathrm{NaOH}$ buffer. Controls were set by adjusting NB medium to different $\mathrm{pH}$ values. 
The effects of different metal ions on degradation were determined by adding $\mathrm{Mg}^{2+}, \mathrm{Zn}^{2+}, \mathrm{Cu}^{2+}, \mathrm{Mn}^{2+}$ and $\mathrm{Co}^{2+}$ in the form of $\mathrm{MgSo}_{4}, \mathrm{ZnSO}_{4}, \mathrm{CuSO}_{4}, \mathrm{MnSo}_{4}$ and $\mathrm{Co}\left(\mathrm{No}_{3}\right)_{2}$, respectively, to the reaction mixtures, respectively resulting in a final ion concentration of $10 \mathrm{mM}$. NB was used to substitute culture supernatant in the control. The AFs degradation tests were performed as described above previously.

\section{Results}

Isolation and purification of bacterial isolates

In the present study, a medium containing coumarin (CM) was used for selection of aflatoxins (AFs) degrading microbes. The microorganisms grew and very few colonies appeared on the medium. Pure isolates only were subcultured on slants of NA. From 43 culture isolates about 9 bacterial cultures were able to degrade aflatoxins as shown in Table 1.

Screening the ability of bacterial cultures on the degradation of aflatoxins by HPLC

The isolates of bacterial cultures able to degrade AFs on TLC were taken for further analysis on HPLC. Nine bacterial isolates were capable of decreasing AFs concentrations in the liquid medium with different values. Three isolates reduced AFs in the medium by ratio up to $90 \%$ (Table 2). HPLC analysis showed the absence of peaks in the samples treated with isolated cultures corresponding to standard AFs sample (Fig. 1).

Screening of the ability of CFS and cell extract (ppt) of selected bacterial isolates on AFs degradation using TLC analysis

The CFS of bacterial isolates which showed high degradation ratio (code's CaG6, CaG7 and IsW1) were screened for their ability to degrade AFs using TLC. As observed from TLC analysis, Fig. 2 and 3, respectively, showed no or few degradation of AFs by bacterial CFS.

Degradation of aflatoxins by bacterial CFS using HPLC analysis

BacterialCFS were subsequently investigated for their ability to degrade AFs using HPLC analysis. Different levels of AFs were observed. Results from Table 3 showed a percent of about $(65,76.3,81.1 \%)$ of AFs degradation as compared to standard sample. As shown in
Table 4 CFS of bacterial isolates exhibited less degradation activity compared to degradation by cell culture. The highest degradation rate was observed by bacterial isolate (CaG6) CFS with degradation rate $65 \%$ compared to $86 \%$ by bacterial cell culture while degradation rate by CFS of bacterial isolate (IsW1) was $76.3 \%$ compared to $85.5 \%$ by cell culture, and bacterial isolate (IsW1) showed degradation activity reached $81.1 \%$ by CFS compared to $85.7 \%$ by cell culture.

Inhibition of Aspergillus flavus NRRL 3145 (aflatoxin producing strain) by selected bacterial isolates

The three bacterial isolates $\mathrm{CaG} 6, \mathrm{CaG} 7$ and IsW1 inhibited the aflatoxin producing fungi to varying extents (Fig. 4). Highest inhibition (30mm) was observed with CaG6.

Molecular characterization of the most potent aflatoxins degrading bacterial isolate (code CaG6)

The identification of the highly AFs degrading bacterial isolate CaG6 was confirmed by using $16 \mathrm{~S}$ rRNA gene sequencing as Bacillus cereus. Then sequence was submitted to GeneBank in accession number MG751322 with $99 \%$ similarity to Bacillus cereus category (Fig. 5).

Screening the ability of CaG6 on under optimum conditions of temperature, $\mathrm{pH}$ and metal ions for degradation of AFs by Bacillus cereus using HPLC analysis

From TLC results the optimum conditions for AFs degradation was observed during incubation at $\mathrm{pH} 8.0$ for $48 \mathrm{~h}$ at $37^{\circ} \mathrm{C}$ with addition of $\mathrm{Mn}^{2+}$ ions. These results were taken for further analysis on HPLC. Bacillus cereus showed more degradation ability at optimum conditions compared to isolates without optimization (Table 5).

\section{Discussion}

Aflatoxins (AFs) are furano-coumarin compounds and considered the most studied mycotoxin group, comprising aflatoxin $\mathrm{B}_{1}\left(\mathrm{AFB}_{1}\right)$ (Williams et al., 2004). Foods contaminated with $\mathrm{AFB}_{1}$ have a high carcinogenic potency for humans. It is therefore important to find a microbe or an enzyme possessing wide exclusion activity against most of mycotoxins. 
TABLE 1. Screening of aflatoxins biodegradation by different bacterial isolates using TLC method.

\begin{tabular}{|c|c|c|c|c|c|}
\hline Isolate No. & Isolate code & Cultivated plant & Region & Morphology of isolates & TLC results \\
\hline 1 & Shw1 & wheat & Sharkia & Creamy colony & - \\
\hline 2 & ShW2 & wheat & Sharkia & Creamy colony & - \\
\hline 3 & ShW3 & wheat & Sharkia & Creamy colony & - \\
\hline 4 & ShT1 & Trifolium & Sharkia & Creamy colony & - \\
\hline 5 & ShT2 & Trifolium & Sharkia & Creamy colony & - \\
\hline 6 & ShT3 & Trifolium & Sharkia & Creamy colony & - \\
\hline 7 & ShT4 & Trifolium & Sharkia & Creamy colony & \\
\hline 8 & $\mathrm{ShC1}$ & Cabbage & Sharkia & Creamy colony & - \\
\hline 9 & $\mathrm{ShC} 2$ & Cabbage & Sharkia & Creamy colony & - \\
\hline 10 & $\mathrm{ShC3}$ & Cabbage & Sharkia & Creamy colony & - \\
\hline 11 & IsW1 & Wheat & Ismalia & Creamy colony & + \\
\hline 12 & IsW2 & Wheat & Ismalia & Creamy colony & - \\
\hline 13 & IsW3 & Wheat & Ismalia & Creamy colony & - \\
\hline 14 & IsW4 & Wheat & Ismalia & Creamy colony & - \\
\hline 15 & IsW5 & Wheat & Ismalia & Creamy colony & + \\
\hline 16 & IsW6 & Wheat & Ismalia & Creamy colony & - \\
\hline 17 & IsW7 & Wheat & Ismalia & Creamy colony & - \\
\hline 18 & CaG1 & Garlic & Cairo & Creamy colony & + \\
\hline 19 & $\mathrm{CaG} 2$ & Garlic & Cairo & Creamy colony & + \\
\hline 20 & $\mathrm{CaG} 3$ & Garlic & Cairo & Creamy colony & - \\
\hline 21 & CaG4 & Garlic & Cairo & Creamy colony & - \\
\hline 22 & CaG5 & Garlic & Cairo & Creamy colony & - \\
\hline 23 & CaG6 & Garlic & Cairo & Creamy colony & + \\
\hline 24 & CaG7 & Garlic & Cairo & yellow colony & + \\
\hline 25 & $\mathrm{DaO} 1$ & Onion & Dakahlia & Creamy colony & - \\
\hline 26 & $\mathrm{DaO} 2$ & Onion & Dakahlia & Creamy colony & - \\
\hline 27 & $\mathrm{DaO} 3$ & Onion & Dakahlia & Creamy colony & - \\
\hline 28 & TaPol & Potato & Tanta & Creamy colony & - \\
\hline 29 & $\mathrm{TaPo} 2$ & Potato & Tanta & Creamy colony & - \\
\hline 30 & TaPo3 & Potato & Tanta & Creamy colony & - \\
\hline 31 & $\mathrm{H} 1$ & Horse feces & Sharkia & Creamy colony & - \\
\hline 32 & $\mathrm{H} 2$ & Horse feces & Sharkia & Creamy colony & + \\
\hline 33 & H3 & Horse feces & Sharkia & Creamy colony & - \\
\hline 34 & $\mathrm{H} 4$ & Horse feces & Sharkia & Yellowcolony & - \\
\hline 35 & H5 & Horse feces & Sharkia & Yellowcolony & + \\
\hline 36 & $\mathrm{P} 1$ & Pigeon feces & Sharkia & Creamy colony & - \\
\hline 37 & $\mathrm{P} 2$ & Pigeon feces & Sharkia & Creamy colony & - \\
\hline 38 & P3 & Pigeon feces & Sharkia & Creamy colony & - \\
\hline 39 & $\mathrm{C} 1$ & Cheap feces & Sharkia & Creamy colony & - \\
\hline 40 & $\mathrm{C} 2$ & Cheap feces & Sharkia & Creamy colony & - \\
\hline 41 & B1 & Buffalo feces & Sharkia & White colony & - \\
\hline 42 & B2 & Buffalo feces & Sharkia & Creamy colony & + \\
\hline 43 & B3 & Buffalo feces & Sharkia & Creamy colony & - \\
\hline
\end{tabular}

$\mathrm{Sh}=$ Sharkia Governorate, Is= Ismalia Governorate, $\mathrm{Ca}=$ Cairo Governorate, Da $=$ Dakahlia Governorate, $\mathrm{Ta}=$ Tanta Governorat, $\mathrm{W}=$ Farm soil cultivated withwheat, $T=$ Farm soil cultivated with trifolium, $G=$ Farm soil cultivated with garlic, $O=$ Farm soil cultivated with onion, $\mathrm{P}=$ Farm soil cultivated with potato, $\mathrm{H}=$ Horse feces, $\mathrm{P}=$ Pigeon feces, $\mathrm{C}=$ Sheep feces, $\mathrm{B}=\mathrm{Buffalo}$ feces. $1,2,3, \ldots . .=$ No. of bacterial isolates.

-= No Afs degradation $\quad+=$ There is degradation 
TABLE 2. Bacterial isolates reduced AFs concentration in liquid medium by HPLC.

\begin{tabular}{lccc}
\hline Isolate no. & Active isolate & $\begin{array}{c}\text { Total concentration Of AFs }+ \\
\text { isolate culture }\end{array}$ & Ratio of total degradation \% \\
\hline 1 & $\mathrm{~B} 2$ & 243.81 & 81.2 \\
2 & $\mathrm{CaG} 1$ & 344.88 & 73.4 \\
3 & $\mathrm{H} 5$ & 160.9 & 87.6 \\
4 & $\mathrm{H} 2$ & 385.77 & 70.3 \\
5 & $\mathrm{IsW} 5$ & 245.63 & 81.1 \\
\hline 6 & $\mathrm{IsW} 1$ & 120.08 & 90.7 \\
7 & $\mathrm{CaG} 6$ & 69.18 & 98.1 \\
8 & $\mathrm{CaG} 7$ & 24.62 & 94.6 \\
\hline 9 & $\mathrm{CaG} 2$ & 205.21 & 84.2 \\
\hline Standard aflatoxin & & 1300 & \\
(P.P.b) & & & \\
\hline
\end{tabular}

Is $=$ Ismalia Governorate, $\mathrm{Ca}=$ Cairo Governorate, $\mathrm{W}=$ Farm soil cultivated with wheat, $\mathrm{G}=$ Farm soil cultivated with garlic, $\mathrm{H}=\mathrm{Horse}$ feces, $\mathrm{B}=$ Buffalo feces, $\mathrm{H}=$ Horse feces, $\mathrm{F}=$ Fungi.

$1,2,3, \ldots=$ No. of isolates.

Data of HPLC of aflatoxins + different bacterial isolates

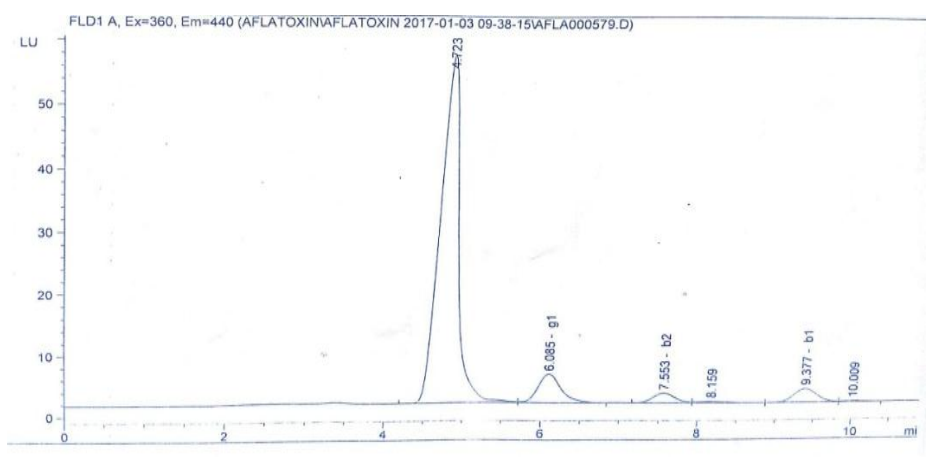

Biodegradation ofaflatoxins (AFs) by isolate 1 (code B2).

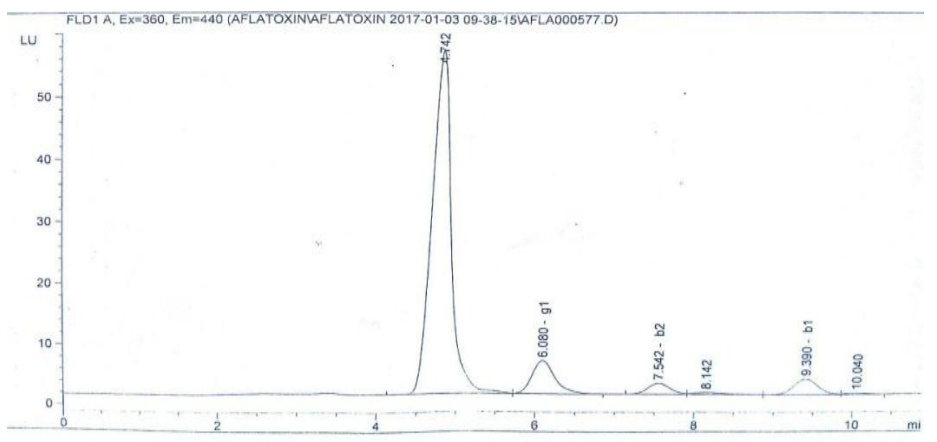

\section{Data of HPLC of standard}

aflatoxins.

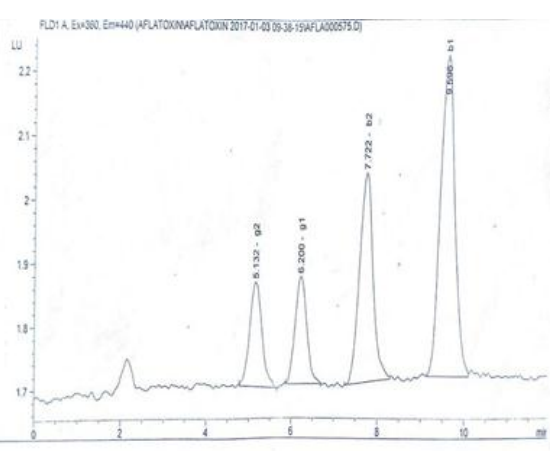

Biodegradation of aflatoxins (AFs) by isolate 2 (code

H2). 
Biodegradation of aflatoxins (AFs) by isolate 2 (code

H2).

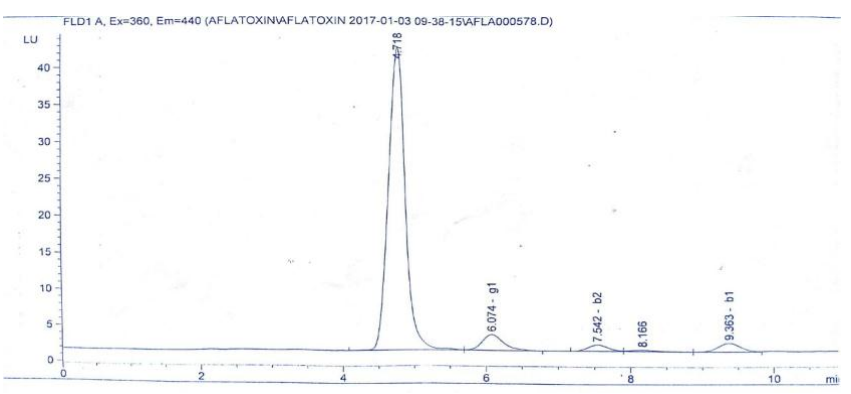

Biodegradation of aflatoxins (AFs) by isolate 3 (code

H5).

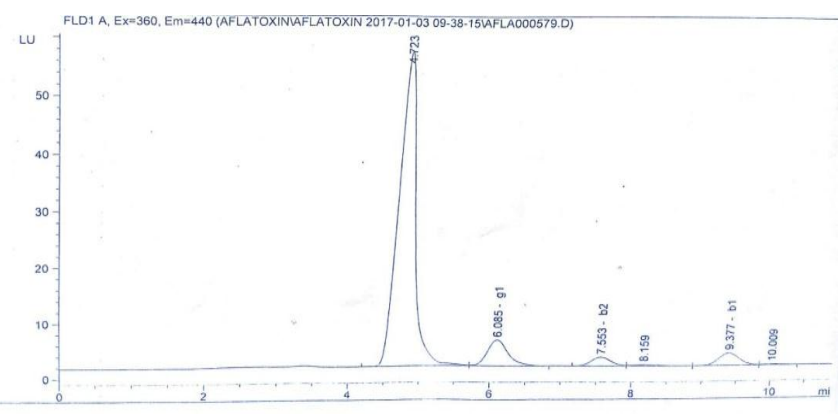

Biodegradation of aflatoxins (AFs) by isolate 4 (code

CaG1).

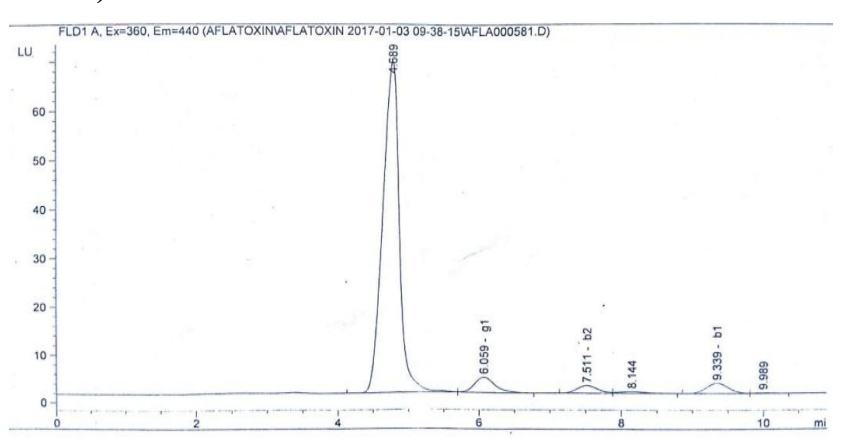

Biodegradation of aflatoxins (AFs) by isolate 5 (code IsW5).
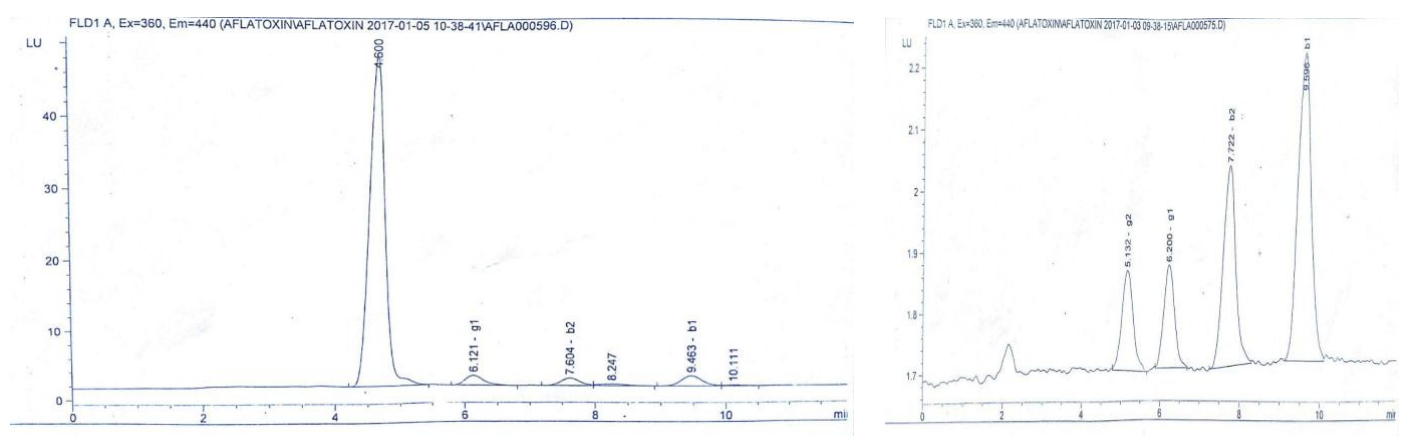

Biodegradation of aflatoxins (AFs) by isolate 6 (code IsW1).
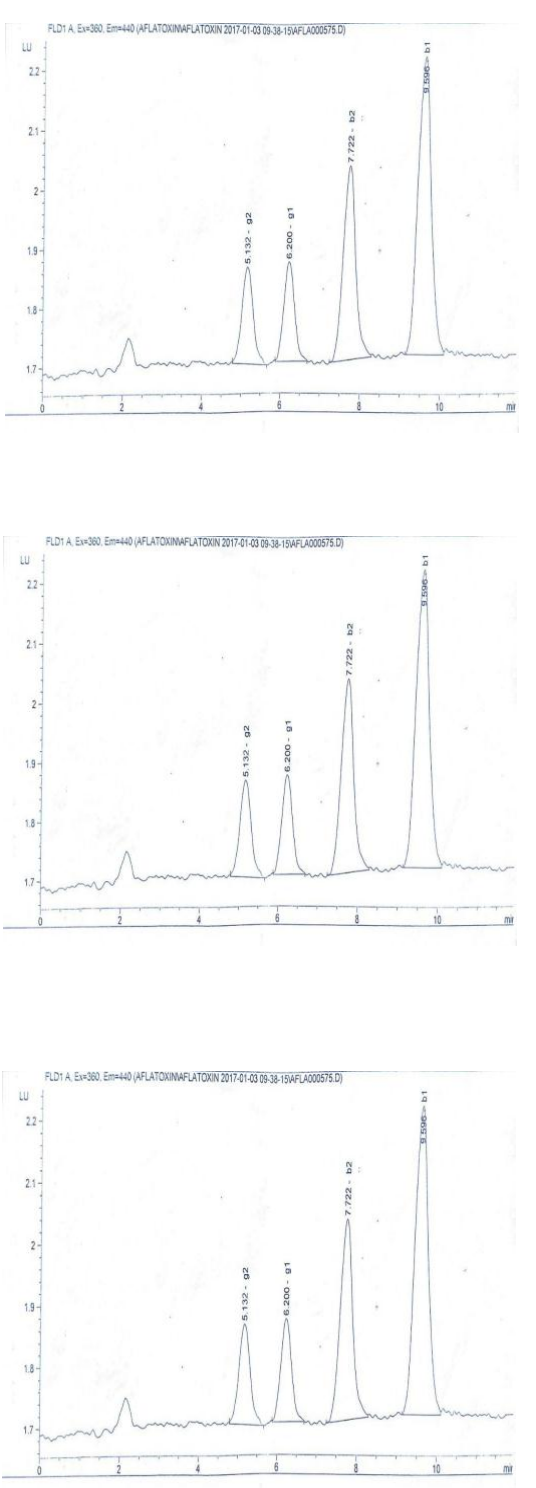



Biodegradation of aflatoxins (AFs) by isolate 7 (code

CaG7).
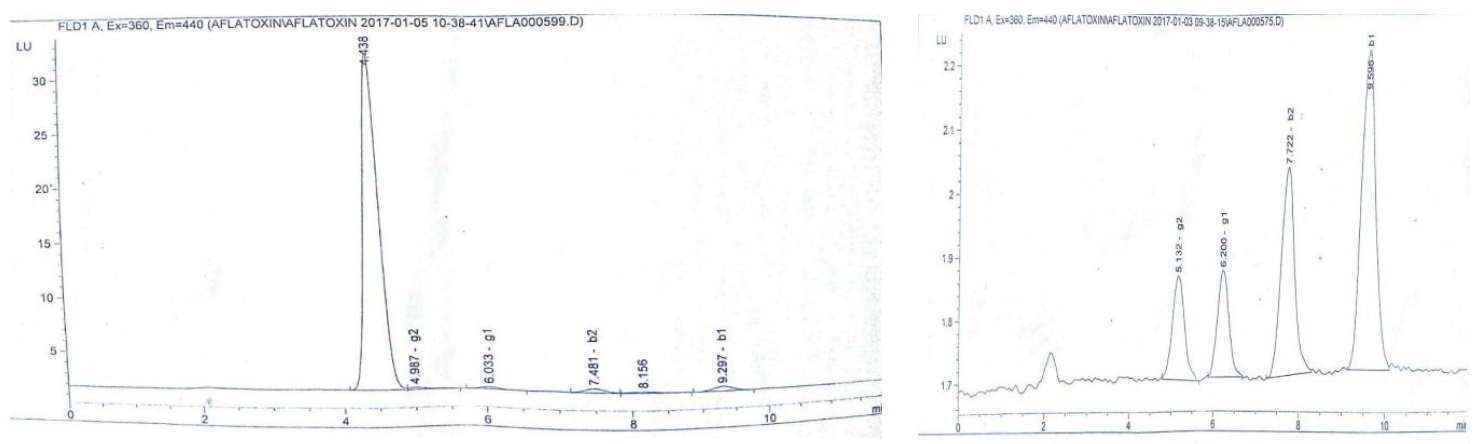

Biodegradation of aflatoxins (AFs) by isolate 8

(codeCaG6).
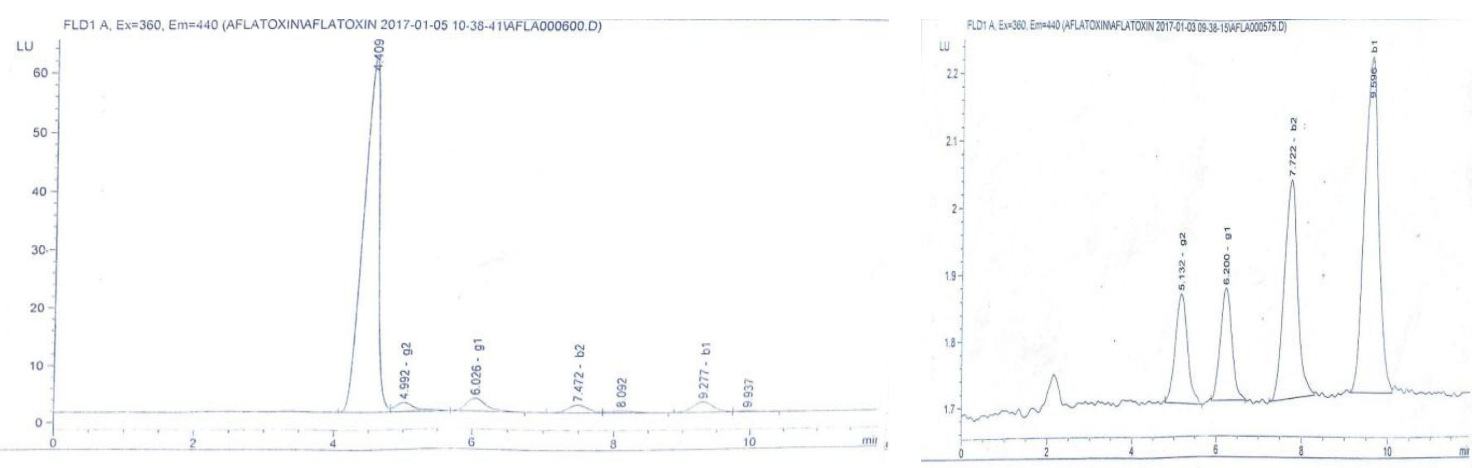

Biodegradation of aflatoxins (AFs) by isolate 9 (code

CaG2).

Fig. 1. HPLC chromatogram of AFs degradation by bacterial isolates. 


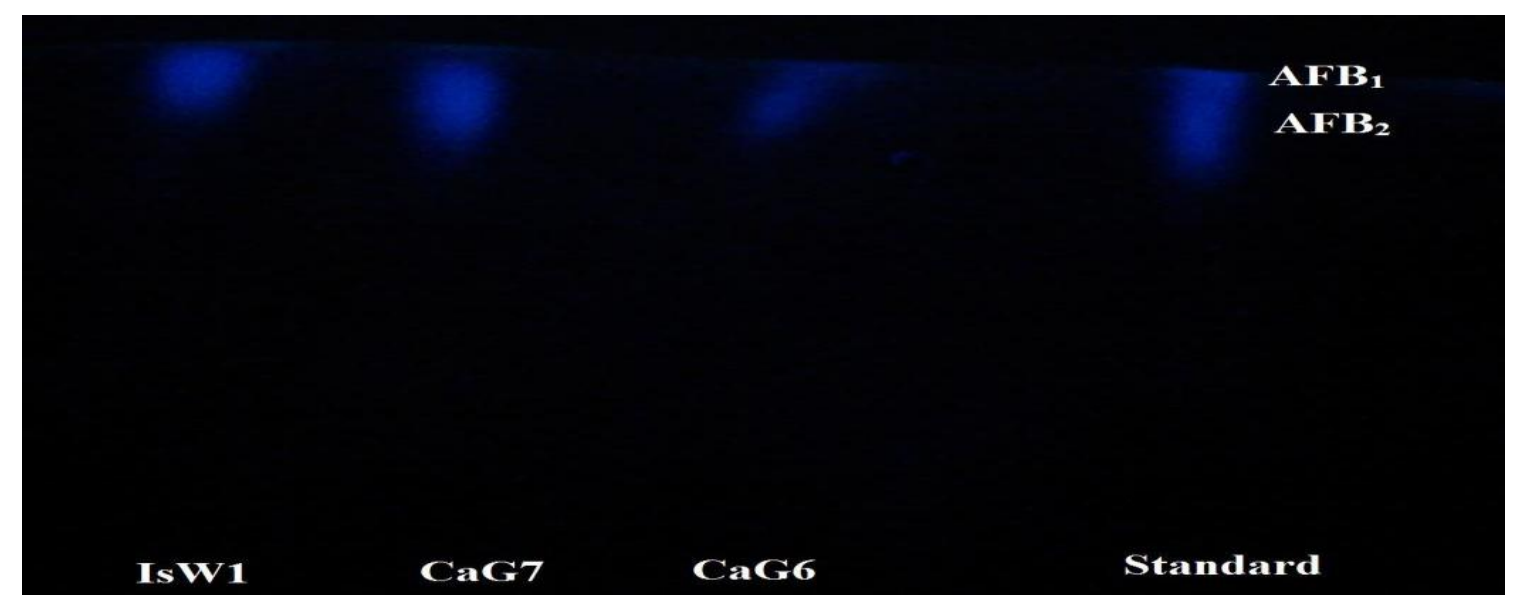

Fig. 2. TLC analysis indicate the activity of aflatoxin-degradation by bacterial CFS.

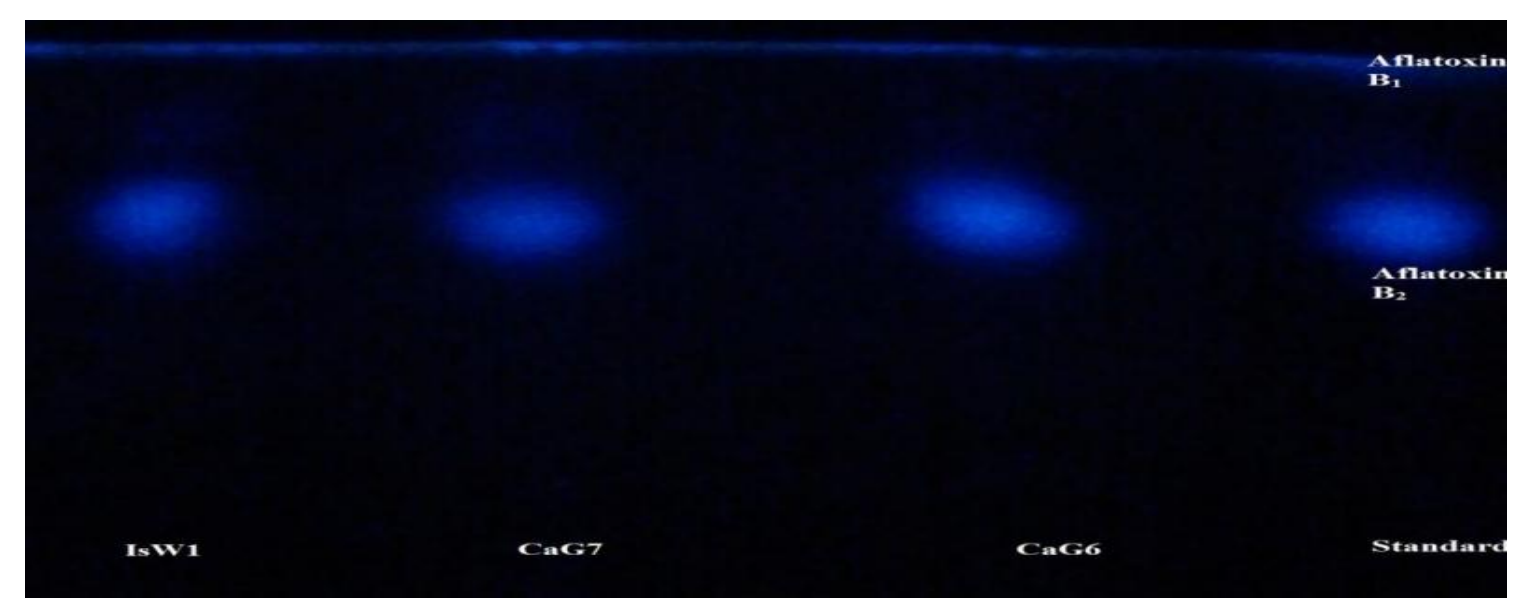

Fig. 3. TLC analysis indicate the activity of aflatoxin-degradation by bacterial ppt.

TABLE 3. Biodegradation of aflatoxins (AFs) by CFS of bacterial isolates.

\begin{tabular}{|c|c|c|c|c|c|c|c|}
\hline $\begin{array}{l}\text { Type of } \\
\text { aflatoxins }\end{array}$ & $\begin{array}{c}\text { Concentration } \\
\text { of AFs of } \\
\text { control } \\
\text { (ppb) }\end{array}$ & $\begin{array}{c}\text { Concentration } \\
\text { of AFs (ppb) of } \\
\text { control+isolate } 1 \\
\text { (CaG6) }\end{array}$ & $\begin{array}{l}\text { \% of bio- } \\
\text { degradation } \\
\text { of AFs }\end{array}$ & $\begin{array}{c}\text { Concentration } \\
\text { of AFs (ppb) of } \\
\text { control +isolate2 } \\
\text { (CaG7) }\end{array}$ & $\begin{array}{c}\% \text { of bio- } \\
\text { degradation } \\
\text { of AFs }\end{array}$ & $\begin{array}{c}\text { Concentration } \\
\text { of AFs (ppb) of } \\
\text { control +isolate3 } \\
\text { (IsW1) }\end{array}$ & $\begin{array}{l}\text { \% of bio- } \\
\text { degradation } \\
\text { of AFs }\end{array}$ \\
\hline $1-\mathrm{AFB}_{1}$ & 22.8 & 3.4 & 85 & 5.5 & 75.8 & 3.2 & 85.9 \\
\hline $2-\mathrm{AFB}_{2}$ & 7.6 & 1.4 & 81.5 & 0.5 & 93.4 & 1.3 & 82.8 \\
\hline $3-\mathrm{AFG}_{1}$ & 206.6 & 34.8 & 83.1 & 45.6 & 77.9 & 30.1 & 85.4 \\
\hline $4-\mathrm{AFG}_{2}$ & 72.9 & 68.8 & 5.6 & 21.6 & 70.3 & 21.6 & 70.3 \\
\hline $\begin{array}{l}5 \text {-Total } \\
\text { AFs }\end{array}$ & 310.1 & 108.4 & 65 & 73.2 & 76.3 & 56.2 & 81.1 \\
\hline
\end{tabular}


TABLE 4. Biodegradation of aflatoxins (AFs) by CFS of bacterial isolates (with degradation activity over than $\mathbf{9 0 \% )}$ compared to degradation by culture of isolates using HPLC.

\begin{tabular}{lccccc}
\hline Isolate No. & Isolate code & $\begin{array}{c}\text { Total conc. of } \\
\text { AFs+CFS } \\
\text { of isolates }\end{array}$ & $\begin{array}{c}\text { \% of } \\
\text { degradation by } \\
\text { CFS }\end{array}$ & $\begin{array}{c}\text { Total conc. Of } \\
\text { AFs+cell culture of } \\
\text { isolates }\end{array}$ & $\begin{array}{c}\text { \% of degradation } \\
\text { by cell culture }\end{array}$ \\
\hline 1 & CaG6 & 108.4 & 65 & 43.3 & 86 \\
\hline 2 & CaG7 & 73.2 & 76.3 & 44.7 & 85.5 \\
\hline 3 & IsW1 & 56.2 & 81.1 & 44.3 & 85.7 \\
\hline $\begin{array}{l}\text { Standard AFs } \\
\text { for bacteria (P. P. b.) }\end{array}$ & & 310.1 & & 310.1 & \\
\hline
\end{tabular}

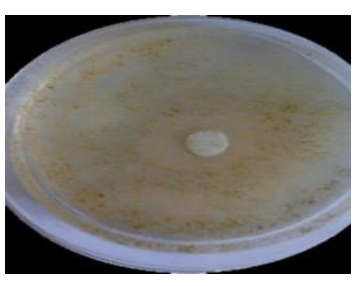

IsW1

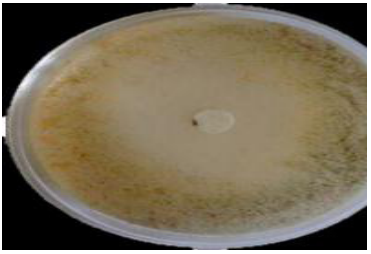

CaG6

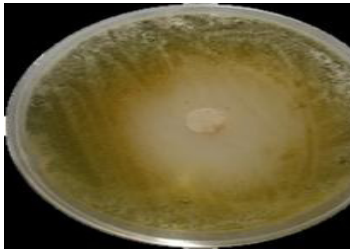

CaG7

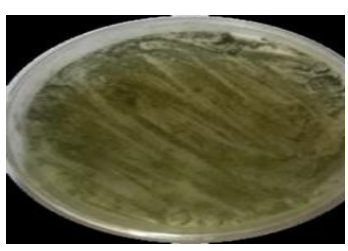

Control

Fig. 4. The inhibition effect of bacterial isolates and fungal isolate on A.flavus NRRL 3145.

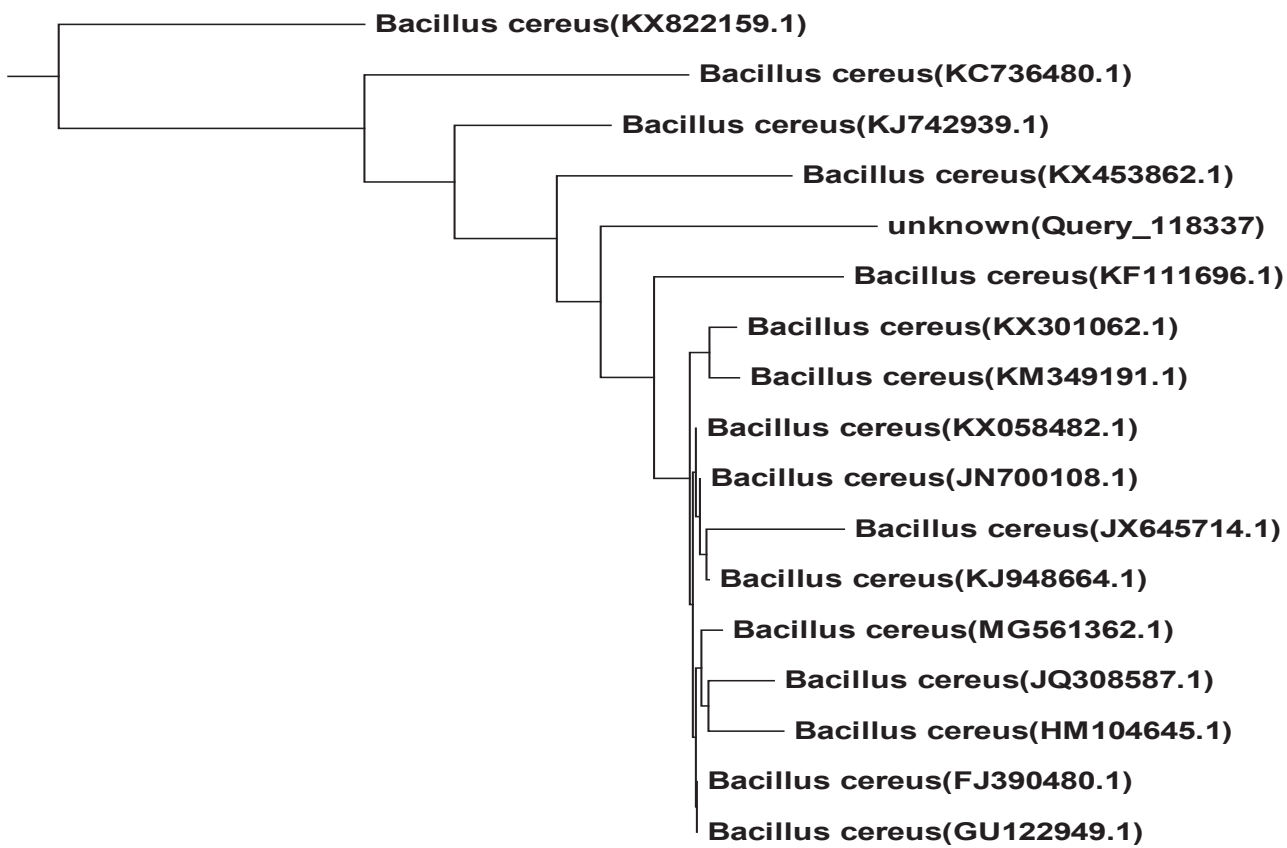

0.0050

Fig. 5. Phylogenetic tree of Bacillus cereus CaG6 strain. 
TABLE 5. Biodegradation of aflatoxins (AFs) by Bacillus cereus CaG6 under optimum conditions.

\begin{tabular}{|c|c|c|c|c|c|}
\hline $\begin{array}{l}\text { Type of } \\
\text { aflatoxins }\end{array}$ & $\begin{array}{c}\text { Concentration } \\
\text { of AFs of control } \\
\text { (ppb) }\end{array}$ & $\begin{array}{c}\text { Concentration of AFs } \\
\text { (ppb) of control + } \\
\text { B. cereus CaG6 } \\
\text { (without } \\
\text { optimization) }\end{array}$ & $\begin{array}{c}\% \text { of biodegradation } \\
\text { of AFs (without } \\
\text { optimization) }\end{array}$ & $\begin{array}{c}\text { Concentration } \\
\text { of AFs (ppb) of } \\
\text { control + } \\
\text { B. cereus } \\
\text { CaG6 } \\
\text { (at optimum } \\
\text { conditions) }\end{array}$ & $\begin{array}{c}\% \text { of } \\
\text { biodegradation of } \\
\text { AFs(at optimum } \\
\text { conditions) }\end{array}$ \\
\hline $1-\mathrm{AFB}_{1}$ & 22.8 & 2.6 & 88.5 & 2.4 & 89.4 \\
\hline $2-\mathrm{AFB}_{2}$ & 7.6 & 1.03 & 86.4 & 0.9 & 88.1 \\
\hline $3-\mathrm{AFG}_{1}$ & 206.6 & 15.4 & 92.5 & 6.2 & 96.9 \\
\hline 4- $\mathrm{AFG}_{2}$ & 72.9 & 24.3 & 66.6 & 2.6 & 96.4 \\
\hline 5-Total & 310.1 & 43.3 & 86 & 12.03 & 96.1 \\
\hline $\mathrm{AFs}$ & & & & & \\
\hline
\end{tabular}

In this study, fourty three bacterial isolates isolates could be isolated from various sources including cultivated soils and animal feces from different governorates in Egypt. The isolation was occurred on media contain coumarin as a part of its composition. Hence, microorganisms that could consume coumarin and use it as their carbon source might be able to use AFs (Guan et al., 2008).

This process called cometabolism which is the process through which a contaminant is accidentally decomposed by an enzyme or cofactor secreated during microbial metabolism of another complex. Typically, the microorganism involved has no benefit. Only indigenous microbes that is abile to degrade the contaminant and cosubstrate is stimulated by this strategies. This greatly targeted stimulation assures that only those microbes that is capable of degrading the contaminant are targeted, so reducing amendment costs, well and formation plugging, etc. (Hazen, 2010). So, using coumarin provided a cheap, viable, and effective tool for selecting aflatoxin $\mathrm{B}_{1}$ degrading microorganisms (Zhang et al., 2014).

In this study, the fourty three different isolates were screened for their ability to degrade AFs using thin layer chromatography analysis (TLC). Out of 43 isolates, Nine isolates showed reduction activity of AFs by different ratios. The degradation by different isolates was taken for further analysis using high performance liquid chromatography
(HPLC). The analysis indicated that the different isolates reduced AFs by high ratio that reached $98.1 \%$.

In the present study, cell culture, cell free supernatant (CFS) and cell ppt of isolates were tested for their degradation ability. In contrast to results obtained by Guan et al. (2008) who found that $\mathrm{AFB}_{1}$ degradation by Culture supernatant of $S$. maltophilia 35-3 was greater than degradation by viable cells and cell extracts, cell culture showed strong AFs degradaing activity compared to CFS while cell extract couldn't exhibit any degrading effect.

Further more, the most potent bacterial and fungal isolates which show high degradation activity were selected. Bacterial isolates with the highest degradation identified as Bacillus cereus MG751322 by investigation of 16S rRNA gene sequences. Bacillus cereus is an significant cause of food borne disease and food poisoning. However, B. cereus has been used as a probiotic in human medication and livestock production, with low standards of safety assessment (Zhu et al., 2016). B.cereus MG751322 had the strongest ability to detoxify AFs, where the degradation percentages of AFs was $98 \%$ after $24 \mathrm{~h}$ of incubation.

The results from TLC showed that the optimum conditions for AFs degradation by B. cereus MG751322 was at $\mathrm{pH}$ 8.0. The 
degradation was not observed at $\mathrm{pH} 4.0$ and 5.0 and increase gradually till reached maximum degradation rate at $\mathrm{pH}$ 8.0. This result agreed with $\mathrm{AFB}_{1}$ degradation by of S. maltophilia 35-3 CFS in which the maximum degradation (84.8\%) was observed at pH 8.0 (Guan et al., 2008) and degradation of $\mathrm{AFB}_{1}$ by cell extracts of $F$. aurantiacum under different $\mathrm{pH}$ values showed a similar result (Smiley \& Draughon, 2000), while the highest degradation rate ofAFB $(91.24 \%)$ by B. licheniformis CFR1was obtained at $\mathrm{pH}$ of 7 (Rao et al., 2017).

The optimum temperature for AFs degradation by B. cereus MG751322 was observed at $37^{\circ} \mathrm{C}$. Also low degradation obtained at $20^{\circ} \mathrm{C}$. The same results obtained by Guan et al. (2008) who stated that the AFB degradation by culture supernatant of S. maltophilia 35-3 was higher at $37^{\circ} \mathrm{C}(78.7 \%)$ $(\mathrm{P}<0.05)$ and also Rao et al. (2017) reported that a maximum degradation by $B$. licheniformis was at $37^{\circ} \mathrm{C}$. By increasing temperature the degradation rate increase, till reach $37^{\circ} \mathrm{C}$. $\mathrm{AFB}_{1}$ degradation by $R$. erythropolis and $M$. fluoranthenivorans cell extracts were around the same in between 10$40^{\circ} \mathrm{C}(>90 \%)$ (Teniola et al., 2005).

The maximum degradation rate of AFs by $B$. cereus MG751322 was obtained after incubation for $24 \mathrm{~h}$, and by addition of $\mathrm{Mn}^{2+}$ ions, Also combined microbes as Lactobacillus casei, Bacillus subtilis and Pichia anomala showed maximum degradation of $\mathrm{AFB}_{1}$ was between 24 and 48 h (Zuo et al., 2012) while $78.7 \%$ of $\mathrm{AFB}_{1}$ degraded by the culture supernatant of $\mathrm{S}$. maltophilia 35-3 after 72h (Guan et al., 2008) and $93.57 \%$ of $\mathrm{AFB}_{1}$ degraded by $B$. licheniformis after 72h (Rao et al., 2017).

AFs degradation by the cell culture of $B$. cereus MG751322 could be stimulated by $\mathrm{Mn}^{2+}$ ions, also $\mathrm{Mg}^{2+}$ showed high reduction effect on $\mathrm{AFB}_{1}$ degradation and on the four types of AFs generally, and addition of $\mathrm{Zn}^{2+}$ showed no effect on degradation rate while, $\mathrm{Cu}^{2+}$ ions reduced AFs obviously. The same results obtained by D'Souza and Brackett about the effects of $\mathrm{Mg}^{2+}$ on $\mathrm{AFB}_{1}$ degradation by $F$. aurantiacum. Also, $\mathrm{AFB}_{1}$ degradation ability by $B$. licheniformis stimulated by addition of $\mathrm{Cu}^{2+}$ and $\mathrm{Mg}^{2+}$ (Rao et al., 2017).

\section{Conclusion}

This study showed more than $90 \%$ degradation of AFs by Bacillus cereus. Thus, Bacillus cereus might be an excellent candidate for bioremediation and detoxification of AFs from both field and food matrices. The results reported in this study could contribute towards the development of food and feeds additives for the detoxification of AFs to improve, safeguard and ensure the quality of foods and feeds.

\section{References}

Afsah-Hejri, L., Jinap, S., Hajeb, P., Radu, S. and Shakibazadeh, S. (2013) A review on mycotoxins in food and feed: Malaysia case study. Compr. Rev. Food Sci. Food Saf, 12(6), 629-651.

Association of official Analytical Chemists (AOAC) (2006) "Official Methods of Analysis", 18 ${ }^{\text {th }}$ ed., Association of Official Analytical Chemists, Washington, D.C.

Ben Salah-Abbes, J., Abbes, S., Jebali, R., Haous, Z. and Oueslati, R. (2015) Potential preventive role of lactic acid bacteria against aflatoxin M1 immunotoxicity and genotoxicity in mice. $J$. Immunotoxicol. 12(2), 107-14.

Cao, H., Liu, D.L., Mo, X.M., Xie, C.F. and Yao, D.S. (2011) A fungal enzyme with the ability of aflatoxin B1 conversion: Purification and ESIMS/ MS identification. Microbiol. Res. 166, 475-483.

Chawanthayatham, S., Thiantanawat, A., Egner, P.A., Groopman, J.D., Wogan, G.N., Croy, R.G. and Essigmann, J.M. (2015) Prenatal exposure of mice to the human liver carcinogen aflatoxin B1 reveals a critical window of susceptibility to genetic change. Int. J. Cancer, 136(6), 1254-62.

El-Shirbiny, E.A.A. (1990) Studies on the antimicrobial activities of some bacteria belonging to Actinomycetales. Ph.D. Thesis. Bot. Depat. Zagazig Univ., Egypt.

Guan, S., Ji, C., Zhou, T., Li, J., Ma, Q. and Niu, T. (2008) Aflatoxin B1 degradation by Stenotrophomonas maltophilia and other microbes selected using coumarin medium. Int. J. Mol. Sci. 9, 1489-1503.

Hazen, T.C. (2010) Cometabolic Bioremediation. In: "Handbook of Hydrocarbon and Lipid Microbiology", Timmis, K.N. (Ed.). Springer, Berlin, Heidelberg. 
IARC, (2015) Mycotoxin control in low - and middle income countries. Lyon, France: International Agency for Research on Cancer (WHO). Report No. 9. pp. 31-42.

Lombard, M.J. (2014) Mycotoxin exposure and infant and young child growth in Africa: What do we know? Ann. Nutr. Metabol. 64, 42-52.

Monica, C. (1985) Medical laboratory manual for tropical countries. English language book society editions. Tropical Health Technology, 42, 250-290.

Oplatowska-Stachowiak, M., Sajic, N., Xu, Y., Haughey, S.A., Mooney, M.H., Gong, Y.Y., Verheijen, R. and Elliott, C.T. (2016) Fast and sensitive aflatoxin B1 and total aflatoxins ELISAs for analysis of peanuts, maize and feed ingredients. Food Control, 63, 239-245.

Oxoid, L. (1982) "The Oxoid Manual of Culture Media Ingredients and Other Laboratories Services", $5^{\text {th }}$ ed. Turnergrabhic, Ltd. England.

Pankaja, S.K., Shib, Hu. and Kevin, M. K. (2018) A review of novel physical and chemical decontamination technologies for aflatoxin in food. Trends Food Sci. Technol. 71, 73-83.

Prettl, Z., Dési, E., Lepossaa, A., Kriszt, B., Kukolya, J. and Nagya, E. (2017) Biological degradation of aflatoxin B1 by a Rhodococcus pyridinivorans strain in by-product of bioethanol. Anim. Feed Sci. Technol. 224, 104-114.

Rao, K.R., Vipin, A.V., Hariprasad, P., Anu Appaiah, K.A. and Venkateswaran. G. (2017) Biological detoxification of Aflatoxin B1 by Bacillus licheniformis CFR1. Food Control, 71, 234-241.

Saeed, S. and Tariq, P. (2007) Antimicrobial activities of Emblica officinalis and Coriandrum sativum against Gram-positive bacteria and Candida albicans. Pak. J. Bot. 39(3), 913-917.

Shehata, S.A. (2002) Detoxification of mycotoxin contaminated animal feedstuffs. Ph.D Thesis, Zagazig Univ., Fac. Agric., Egypt.

Siahmoshteh, F., Hamidi-Esfahani, Z. and RazzaghiAbyaneh, M. (2016) Antifungal activity, biodegradation and production inhibition of aflatoxins B1 and G1 by a soil isolate of Bacillus subtilis against Aspergillus parasiticus NRRL
2999. J. Pure Appl. Microbiol. 10(4): 2541-2549.

Siciliano, I., Spadaro, D., Prelle, A., Vallauri, D., Cavallero, M., Garibaldi, A. and Gullino, M. (2016) Use of cold atmospheric plasma to detoxify hazelnuts from aflatoxins. Toxins (Basel), 8, 125-204.

Smiley, R.D. and Draughon, F.A. (2000) Preliminary evidence that degradation of aflatoxin B1 by Flavobacterium aurantiacum is enzymatic. J. Food Prot. 63, 415-418.

Spadaro, D. and Garibaldi, A. (2017) Containment of mycotoxins in the food chain by using decontamination and detoxification techniques. In: "Practical Tools for Plant and Food Biosecurity", Gullino, M.L., Stack, J., Fletcher, J. and Mumford, J. (Ed.), p. 163-177. Springer, Dordrecht, The Netherlands.

Tamura, K., Stecher, G., Peterson, D., Filipski, A. and Kumar, S. (2013) MEGA6: molecular evolutionary genetics analysis version 6.0. Mol. Biol. Evol. 30, 2725-2729.

Teniola, O.D., Addo, P.A., Brost, I.M., Färber, P., Jany, K.D., Alberts, J.F., van Zyi, W.H., Steyn, P.S. and Holzapfel, W.H. (2005) Degradation of aflatoxin B1 by cell-free extracts of Rhodococcus erythropolis and Mycobacterium fluoranthenivorans sp. nov. DSM44556T. Int. J. Food Microbiol. 105, 111-117.

Thompson, J.D., Higgins, D.G. and Gibson, T.J. (1994) Improving the sensitivity of progressive multiple sequence alignment through sequence weighting, position-specific gap penalties and weight matrix choice. Nucleic Acids Res. 22(22), 4673-4680.

Turner, N.W., Bramhmbhatt, H., Szabo-Vezse, M., Poma, A., Coker, R., and Piletsky, S.A. (2015) Analytical methods for determination of mycotoxins. Anal. Chim. Acta, 901, 12-33.

Wambacq, E., Vanhoutte, I., Audenaert, K., De Gelder, L. and Haesaert, G.(2016) Occurence, preventive and remediation of toxigent fungi and mycotoxins in silage. J. Sci. Food Agric. 96, 2284-2302.

Williams, J.H., Phillips, T.D., Jolly, P.E., Stiles, J.K., Jolly, C.M. and Aggarwal, D. (2004) Human aflatoxicosis in developing countries: A review of toxicology, exposure, potential health consequences, and interventions. Am. J. Clin. Nutr. 80, 1106-1122. 
Wu, Q., Jezkova, A., Yuan, Z., Pavlikova, L., Dohnal, V. and Kuca, K. (2009) Biological degradation of aflatoxins. Drug Metab. Rev. 41(1), 1-7.

Wu, F. (2014) Perspective: Time to face the fungal threat. Nature, 4, 516(7529):S7.

Zhang, W., Xue, B., Li, M., Mu, Y., Chen, Z., Li, J. and Shan, A. (2014) Screening a strain of Aspergillus niger and optimization of fermentation conditions for degradation of aflatoxin B1. Toxins, 6(11), 3157-3172.

Zhu, K., Hölzel, C.S., Cui, Y., Mayer, R., Wang, Y.,
Dietrich, R., Didier, A., Bassitta, R., Märtlbauer, E. and Ding, S. (2016) Probiotic Bacillus cereus strains, a potential risk for public health in China. Front. Microbiol. 7, 718.

Zuo, R., Chang, J., Yin, Q., Wang, P., Cheng, W., Wang, X., Liu, J. and Zheng, Q. (2012) Inhibiting Aspergillus flavus growth and degrading aflatoxin B1 by combined beneficial microbes. Afr. J. Biotechnol. 11(65), 12903-12909.

\section{التكسير الحيوي للأفلاتوكسينات بواسطة البكتريا}

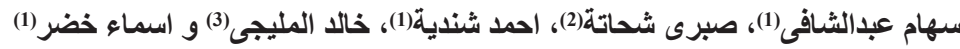

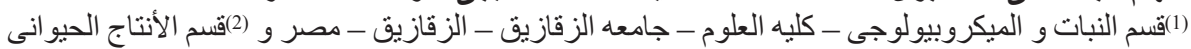

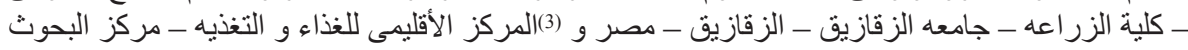

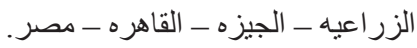

إن الأفلاتوكسينات لها اثار جانبية كبيرة علي الإنسان و المارشية والمحاصيل. فهي تسبب أمر اض خطيرة للإنسان

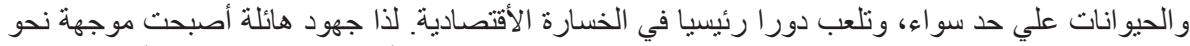

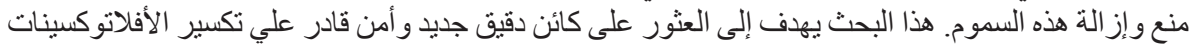

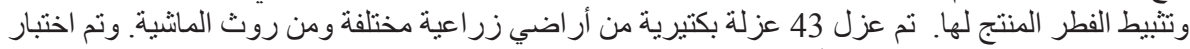

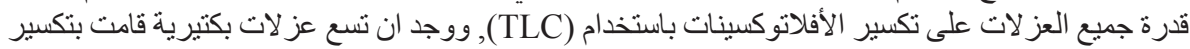



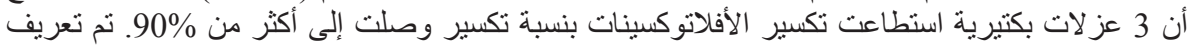

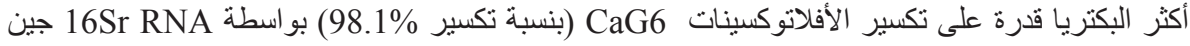

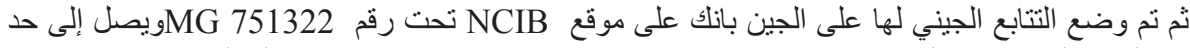
من التشابه لبكتيريا باسيلس سيريس (لهما نسبة تكسير 90.7، 94.6\%, على التو الي) باستخدام نظام VITEK MS على أنهما من رتبة بريفيبياسيلس

.Brevibacillus sp.

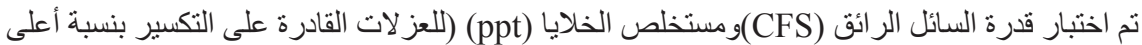

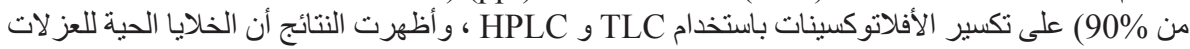

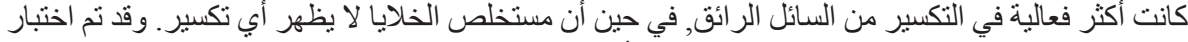



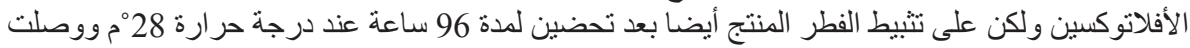

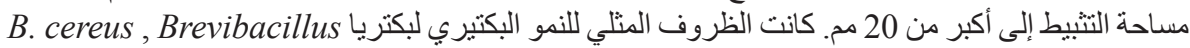


7.0) بعد تحضين لمدة 24 ساعة عند درجة حر ارة 37 مُ م. أوضحت النتائج أن التكسير بو اسطة الخلايا البكتيرية يتحسن بعد إضافة أيونات المنجنيز لونداع 